\title{
Characterization and Redesigning of Mada Batu Small Scale Irrigation Scheme, West Arsi Zone of Oromia Region
}

\author{
Bayan Ahmed \\ Oromia Agricultural Research Institute, Asella Agricultural Engineering Research Center \\ P.O. Box 06, Asella, Ethiopia
}

\begin{abstract}
Irrigation enhances agricultural production, improves the food supply and income of rural population in Ethiopia. From this important viewpoint irrigation projects were widely studied, planned and implemented throughout the country. However, little or no attention was given to the monitoring and evaluation of the performance of already established schemes. The aim of this study was to characterize and redesign of Mada-Batu small scale irrigation scheme in order to improve the performance of the irrigation system. Firstly, scheme was characterized in terms of capacity, dimensions and functionality of reservoir, main and secondary canal and then redesign of the scheme was done depending on the current command area of the scheme. The scheme has trapezoidal shape of reservoir with a capacity of $2604 \mathrm{~m}^{3}$ live storage along with trapezoidal shape of main canal with average size of $161,59,38.2 \mathrm{~cm}$ at the top, bottom and depth respectively and maximum discharge capacity when gate was fully opened at off take was $70 \mathrm{l} / \mathrm{sec}$. The overall efficiency of the scheme is rated at reasonable category. The current redesigned capacity of main canal was $524 \mathrm{l} / \mathrm{s}$ and dimensions of $253.9,74$ and $60 \mathrm{~cm}$ at the top, bottom and depth respectively.
\end{abstract}

Keywords: Mada-Batu, small scale irrigation scheme, characterization, command area, redesigning

DOI: $10.7176 / \mathrm{CER} / 13-3-01$

Publication date:May $31^{\text {st }} 2021$

\section{INTRODUCTION}

Ethiopia has total area coverage of 1.13 million $\mathrm{km}^{2}$, of which 99.3 percent is a land area and the remaining 0.7 percent is covered with water bodies of lakes (MoWR, 2002). The agricultural sector is the leading sector in the Ethiopian economy, 37.2 percent of the total GDP, as compared to 21.3 percent from industry and 41.5 percent from services (CAI, 2016). Though agriculture is the dominant sector, most of Ethiopia's cultivated land is under rain fed agriculture. Due to lack of water storage and large spatial and temporal variations in rainfall, there is no enough water for most farmers to produce more than one crop per year and hence there are frequent crop failures due to dry spells and droughts which have resulted in a chronic food shortage currently facing the country (Seleshi et al., 2007).

Irrigation is one means by which agricultural production can be increased to meet the growing demands in Ethiopia (Seleshi et al., 2005). According to Robel (2005) also indicated that one of the best alternatives to consider for reliable and sustainable food security development is expanding irrigation development on various scales, through river diversion, constructing micro dams, water harvesting structures, etc. The development of irrigation and agricultural water management holds significant potential to improve productivity and reduce vulnerability to climactic volatility in any country (IWMI, 2010).

Considering the current Ethiopian situation with growing population pressure in the highland areas and a rapidly declining natural resource base has necessitated irrigated agriculture and in line with this irrigation is given prime attention on the country's development agenda. The irrigation potential of the country is estimated to be about 3.7 million hectares. Of the total potential, only about 20 to $23 \%$ of this potential is put under irrigated agriculture (both traditional and modern irrigation systems) (NRMD, 2011).

Performance evaluation for any irrigation system is essential to assess how far the goals and objectives set forth at the time of project formulation of the system have been achieved. This is a useful tool to provide necessary feedback for improving the systems management by initiating remedial measures (Rani et al., 2011). The performance evaluation conducted on 26 existing small scale irrigation schemes in south region of the country and identified the majority of them under failing and performing below their capacity (Robel, 2005). Identifying the areas in which they fall short of their potentials is essential. To this effect, it is important to measure and evaluate their success or failure objectively and identify specific areas that need improvement. Hence, reliable measures of the system performance are extremely important for improving efficiency and management decisions. One of such scheme selected for this study to identify the major problem and its performance capacity is Mada-Batu Irrigation Scheme.

The Mada Batu small scale scheme is one of small scale irrigation scheme that was designed to serve limited household of the area but as the population near irrigation scheme was increasing, the farmers were extending their farm land out of designed command and since the scheme was serving for more than 39 years, the reservoir capacity was decreasing due to flood from town deposited sediment to reservoir and the main canal 
was cracked by tree root at different place results water loss. For these reason commands area and water supply of the scheme was not matching even if a water source is good. According to Bayan (2017) performance evaluation conducted on the scheme, the main canal had conveying $70 \mathrm{l} / \mathrm{s}$ which are sufficient to irrigate 103 ha of land but current the commend area are 385 ha. Additionally conveyance efficiency (Ec), application efficiency (Ea) and overall efficiency $\left(E_{0}\right)$ were $64.77,64.54$ and $41.47 \%$ respectively. According to FAO (1989) the overall efficiency of the scheme was fall under interval of the reasonable and most of secondary and tertiary canals were not functional, due to this farmers' diverted water to their own way from division box reaching to their farms. These results scarcity of water and made conflict between the farmers on water use. Hence, this study was made to characterize and redesign the Mada Batu irrigation scheme.

\section{MATERIALS AND METHODS}

\section{Description of the study area}

Mada Batu small-scale irrigation scheme was located in Gedeb Asasa district; West Arsi zone of the Oromia Region. It has a latitude $38^{\circ} 57^{\prime} 3^{\prime \prime} \mathrm{W}-39^{\circ} 25^{\prime} 51^{\prime \prime} \mathrm{E}$ and longitude of $7^{\circ} 21^{\prime} 49^{\prime \prime} \mathrm{N}-7^{\circ} 1^{\prime} 28^{\prime \prime} \mathrm{S}$ with average elevation range 2200 to 4180 m.a.s.l. This district is situated on Addis Ababa to Bale road at a distance of $285 \mathrm{~km}$ and 110 $\mathrm{km}$ from Asella town. The minimum and maximum temperature of the district is found between $12-25.3^{\circ} \mathrm{C}$ and annual mean rainfall $995.6 \mathrm{~mm}$.

\section{Data collection}

The study was conducted during off season from December 2015 to May, 2016 when the crops being cultivated under irrigation. Three locations were selected along the scheme for canal characterization. During the study period regular visit, observations and the primary and secondary data were collected. The primary data such as characterization of irrigation scheme, continues spring discharge measurement and scheme soil texture. For analysis of soil texture 54 soil samples were collected from farmers' fields. The secondary data collected were meteorological data from National Metrological Agency and the history of the irrigation scheme from West Arsi Zone and Gedeb Asasa district Offices of irrigation development authority.

\section{Characterization of irrigation scheme}

The characterization of the scheme was done by field observation and dimension measurements of its reservoir and canals. The reservoir, main and secondary canals were described in terms of their discharge, dimensions and functionality of the scheme elements. Since the reservoir had trapezoidal shape, determination of reservoir capacity was done according to Michael and John (1991) stated for pond capacity calculation of trapezoidal. The top and bottom dimension of dead and live storage were observed and measured. The live storages were measured by closing the night storage at night time and the depth of the water were measured at 24 places at interval of ten meters. The dead storages of the reservoir were also measured by releasing water from the reservoir and the depths of dead storage were taken at 10 place of reservoir at interval of ten meters. Finally the live storage and dead storage were calculated by multiplying individual area with average depth of live and dead storage respectively. Then total reservoir storage was estimated by adding live storage with dead storage. The canal dimension was measured at bottom, top and depth of canal by metering tape at different places.

\section{Determination of crop and irrigation water requirements}

Crop and irrigation water requirements were determined using CROPWAT computer program.

\section{Redesigning the Scheme \\ Hydrological analysis}

Since the spring water was used for irrigation purpose, continuous discharge of flow from the reservoir were measured at different time by Area Velocity Method using current meter at its out let. This continuous discharge at different time was averaged and design of reservoir capacity was determined depending on this discharge.

\section{Cropping pattern}

The irrigation period was started from November to May and the rest months are cultivated by rain. Generally, cropping pattern for the scheme has been considered based on farmers experience in the study area for many years to determine the crop water need at command area. For this four crop types (potato, garlic, carrot and cabbage) were identified.

\section{Irrigation duty}

The amounts of water applied to command area continuously for the entire base period of the crop were determined using the CROPWAT. 


\section{Soil type and canal type design}

Due to costs of construction, water management and maintenance was simple than other canal type, trapezoidal shaped canal were selected. The soil textural class of the irrigation scheme was determined in laboratory and after analysis it was identified using USDA textural triangle, then the assumed design parameters were determined based on identified soil type. Accordingly, redesigning of conveyance system was done using manning equation as stated in equation (1)

$$
\mathrm{Q}=1 / \mathrm{n}^{*} \mathrm{~A} * \mathrm{R}^{2 / 3} \mathrm{~S}^{1 / 2}
$$

In which, $\mathrm{Q}=$ discharge $\left(\mathrm{m}^{3} / \mathrm{s}\right)$

$$
\mathrm{A}=\text { the area of cross-section of flow }\left(\mathrm{m}^{2}\right)
$$

$\mathrm{R}=$ hydraulic radius $(\mathrm{m})$ which is $A / P$. Here, $P$ is the wetted perimeter in $(\mathrm{m})$

$\mathrm{n}=$ Manning's coefficient, and

$$
\mathrm{S}=\text { slope gradient }(\mathrm{m} / \mathrm{m}) \text {. }
$$

Parameters, like maximum allowable flow velocity (i.e., which not cause scouring), manning's roughness coefficient (n) and channel bed slope was assumed depending on soil type and area condition from standard recommended value.

\section{Canal design procedures of manning formula}

Step 1. The discharge (Q), maximum permissible velocity (V), Manning's n, bed slope (S), and side slope (k: 1) are given or have been assumed.

Step 2. Determine the area of cross section from the continuity equation

Step 3. Determine the hydraulic radius, R, from the Manning's formula

Step 4.Determine the wetted perimeter from the relation, $\mathrm{P}=\mathrm{A} / \mathrm{R}$

Step 5: Determine the depth $\mathrm{D}$ and bed width $\mathrm{B}$ from the values of A and $\mathrm{P}$ obtained.

Step 6. Adding free boards

\section{RESULTS AND DISCUSSION}

\section{Characterization of the Irrigation Scheme}

Mada Batu irrigation scheme was established by Ethio-Korean government at the end of 1977 E.C. During the establishment, the scheme was designed to irrigate 200 ha of land. The source of water to irrigate scheme was spring water and has one reservoir, which store's water at night time and supplied to field during day. At rainy season, the gate of reservoir is left open because the farmers use rain water. When the rains pass, the reservoir gate is closed to store water for irrigation.

\section{Soil texture}

From Table 1 the textures of the soil in the three study fields of irrigation scheme fall under loamy soil in all land surface of command area under study. This soil is suitable to grow almost all crops.

Table 1. Laboratory result of soil textural class of Mada Batu irrigation scheme

\begin{tabular}{llll}
\hline Soil properties & \multicolumn{3}{c}{ Soil sampling location } \\
\cline { 2 - 4 } \% sand & US & MS & LS \\
\cline { 2 - 4 } \% silt & 43 & 43 & 48 \\
\% clay & 30 & 33 & 28 \\
Texture class & 28 & 24 & 24 \\
\hline
\end{tabular}

US=upper stream MS=Middle stream LS=Lower stream

\section{Reservoir storage}

The reservoir storage of the scheme was made from earthen dam. It was having trapezoidal shape and had two off takes gate. The first one was having regulated discharge from reservoir to the main canal and the second one was used to discharge excess water from the reservoir. During rainy season when there was high rain, flood collected from town over top drainage canal of the road and flooded to the reservoir. This results in sediment deposition to the reservoir. This was one of the sources for low level of main canal capacity. Currently the capacity of the reservoir is 2604 and $564.3 \mathrm{~m}^{3}$ live and dead storage respectively giving total reservoir storage capacity of $3168.3 \mathrm{~m}^{3}$ (Table 2). 
Table 2.Reservoir dimension and its capacity

\begin{tabular}{ccccccc}
\hline Shape & $\begin{array}{c}\text { Top width } \\
(\mathrm{m})\end{array}$ & $\begin{array}{c}\text { Bottom width } \\
(\mathrm{m})\end{array}$ & $\begin{array}{c}\text { Average water } \\
\text { depth }(\mathrm{m})\end{array}$ & Area $\left(\mathrm{m}^{2}\right)$ & $\begin{array}{c}\text { Reservoir length } \\
(\mathrm{m})\end{array}$ & $\begin{array}{c}\text { Volume } \\
\left(\mathrm{m}^{3}\right)\end{array}$ \\
\hline$(1)$ & $(2)$ & $(3)$ & $(4)$ & $(5)=\left(0.5^{*}(2+3)\right)^{*} 4$ & $(6)$ & $(7=5 * 6)$ \\
A1 & 42.00 & 28.00 & 1.55 & 54.25 & 48.00 & 2604.00 \\
A2 & 28.00 & 26.00 & 0.55 & 14.85 & 38.00 & 564.3 \\
& & & Total & & & $\mathbf{3 1 6 8 . 3}$ \\
\hline
\end{tabular}

$\mathrm{A} 1=$ Reservoir area of live storage $\mathrm{A} 2=$ Reservoir area of dead storage

\section{Main canal}

It was of trapezoidal shape of canal that some parts were lined and others were unlined. The main canal starts from reservoir and convey water for secondary canal and electrical motor pump. It had different dimensions at different place but having the average of $161 \mathrm{~cm}$ top width, $59 \mathrm{~cm}$ bottom width and $38.2 \mathrm{~cm}$ depth. The maximum discharge capacity of the main canal measured when gate was fully opened during the study time at off-take, upper, middle and lower stream were 70, 62, 41, 33 1/sec respectively. From field observation, the main canal section was grass vegetated, bank was eroded, and some part of canal was cracked by trees. These are the main reason for water losses along the canal. This canal currently irrigates 330 ha of farmers land even though it was initially designed to supply for 200 ha.

\section{Secondary canal}

Most of the secondary canals of the scheme were found at middle and lower side of study area. At lower side of scheme existing electrical motor pump was damaged; most of secondary canals were also not functional. Instead of electrical motor pump, the farmer of the right side use individual motor pump to irrigate their farm. Upper site get water from main canal via division box constructed near main canal. Some farms that far from main canal have secondary canals but they were not used due to the fact that some components like water closing gate and division box were damaged. Due to non-functionality of secondary canal, the farmers divert water to its own way from division box reached their farm.

\section{Redesigning the scheme}

The redesign of the scheme is needed due to the current command area and water supply demand of the scheme was not matching. According to Gedeb Asasa irrigation development authority, the scheme was designed to irrigate 200 ha of land but currently farmers were expanded the farm by taking water from the canal by motor pump and as a result the command area is increased to $330 \mathrm{ha}$. Since the scheme has been serving for more than 39 years, the reservoir capacity was decreasing due to sediment deposition to reservoir. It can only take eleven hour to fill the reservoir. Thus, the lower side of the scheme about 55 ha of land of command area was not getting water completely. The command area suitable for irrigation was 385 ha when the canal water supply is modified. That is why; the redesign of the scheme was need.

\section{Scheme water requirement}

Crop water requirement was determined using CROPWAT computer software for major crops irrigated (i.e., potato, garlic, carrot and cabbage) in the area. The output of the model for scheme irrigation requirements of four crops in the command area was shown in Table 3. From this table the highest gross scheme water requirement for those crops in this cropping season was observed in the months of February as $261.8 \mathrm{l} / \mathrm{s}$. So, this is taken as a peak discharge which determines the designs of canal.

Table 3. The four crop patterns in study area

\begin{tabular}{|c|c|c|c|c|c|c|c|}
\hline $\begin{array}{l}\text { Crop } \\
\text { type }\end{array}$ & Irrigation requirement & Dec & Jan & Feb & Mar & Apr & May \\
\hline \multicolumn{2}{|c|}{ Crop patternIrr.req. for actual area (1/s/ha) } & 0.15 & 0.29 & 0.41 & 0.35 & 0.08 & 0.02 \\
\hline & $\begin{array}{l}\text { Gross Irr.req. for actual area }(1 / \mathrm{s} / \mathrm{ha}) \\
\text { for surface }(60 \% \text { eff. })\end{array}$ & 0.25 & 0.48 & 0.68 & 0.58 & 0.13 & 0.03 \\
\hline & Gross Irrig. Req.for 385 ha $(1 / \mathrm{s})$ & 96.25 & 184.80 & 261.80 & 223.30 & 50.05 & 11.55 \\
\hline
\end{tabular}

\section{Operational scheme irrigation needs (SINop)}

From Table 3 the highest gross irrigation requirement for 385 ha was 261.8 1/s which need to flow for 24 hour in scheme but most of working time for irrigation scheme is 12 hour per day. The calculated SINop for 12 hour was $523.6 \mathrm{l} / \mathrm{s}$. So this was the design discharge of main canal for command area. 


\section{Reservoir capacity determination}

The reservoir capacity was determined depending on water required for the command area and continuous flow of spring water from the reservoir. During study time average continuous flow measurement was taken at different time from reservoir (spring water discharge measured after reservoir gate opened and constant water flow reached from reservoir) was $50 \mathrm{l} / \mathrm{s}$ but the canal must supply a discharge of $523.6 \mathrm{l} / \mathrm{s}$ for 12 hour. The current capacity of reservoir as $2604 \mathrm{~m}^{3}$ was measured; however the command areas need $20,476.8 \mathrm{~m}^{3}$ additional water to supply the required amount. Therefore, $20,476.8 \mathrm{~m}^{3}$ is the redesign capacity of reservoir.

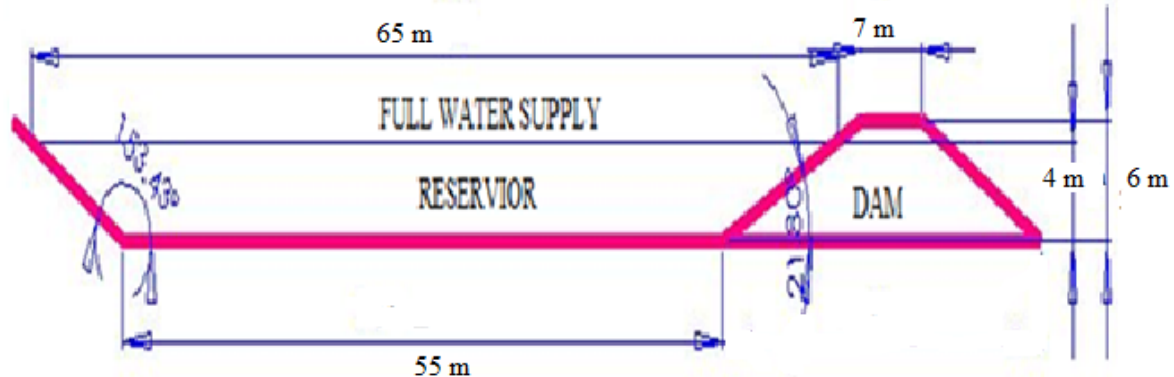

Figure 1. Redesigned reservoir dimension

\section{Distribution structure design}

Since soil of the irrigation scheme was loam, safe side slopes are taken as 1.5:1, Manning's coefficient of 0.02 were assumed and design discharge of 524 1/s was calculated.

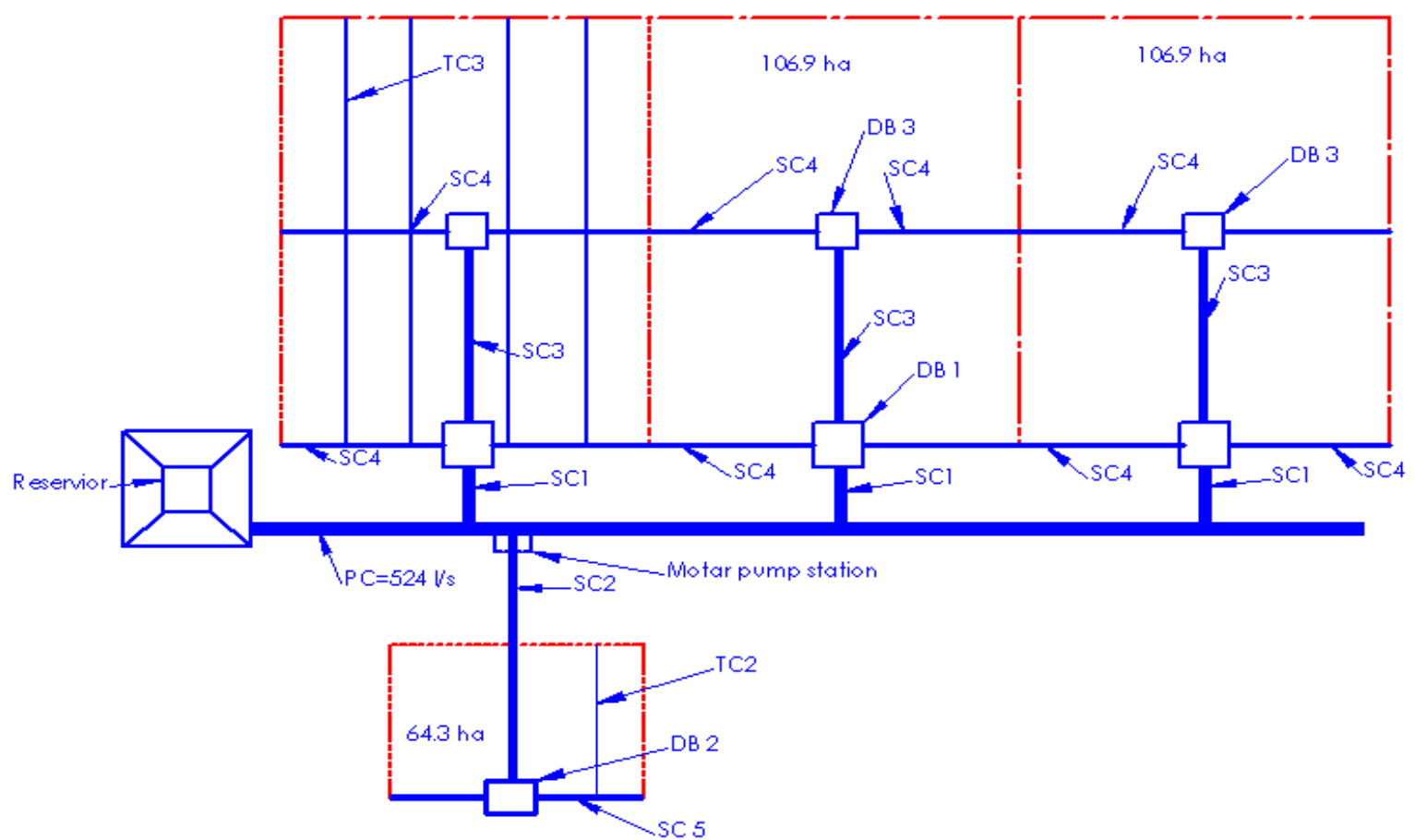

Figure 2. Distribution structure of scheme and command area

\section{Main canal}

The main canal of scheme was started from reservoir and discharges $524 \mathrm{l} / \mathrm{s}$ to command area. The dimensions of the canal were $253.95 \mathrm{~cm}, 74 \mathrm{~cm}$ for top and bottom width and depth of $60 \mathrm{~cm}$. 


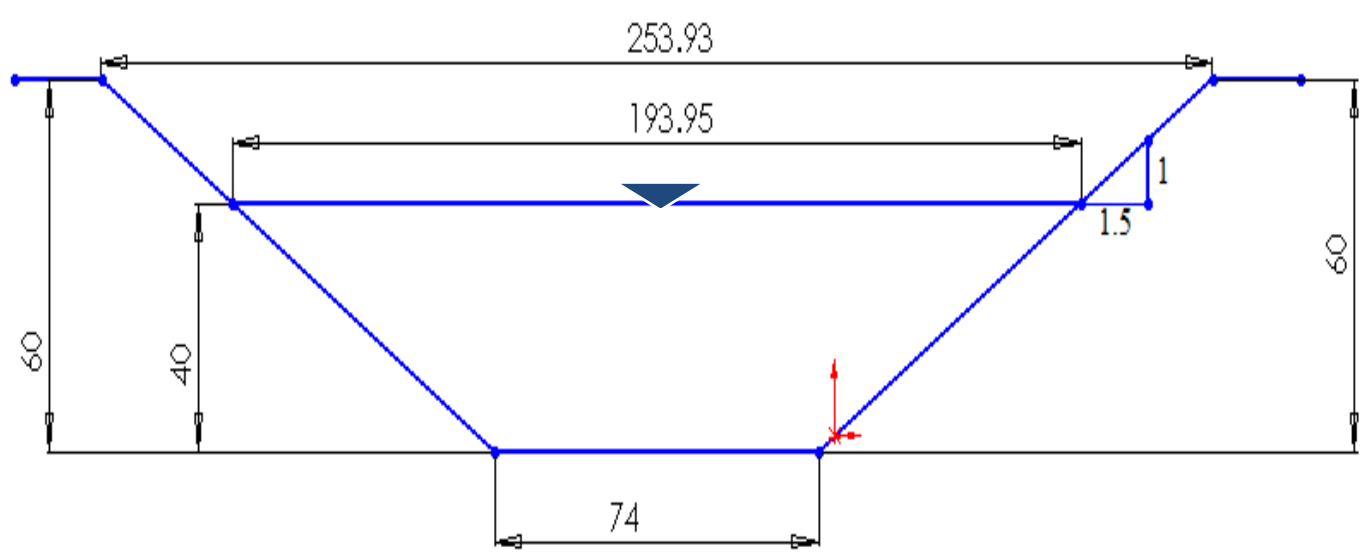

Figure 3. Redesigned main canal dimension in centimeter

\section{Secondary canal}

Table 3 is showing summary of discharge and dimension of secondary and tertiary canals. From this table secondary canal 1 (SC1) off-take $0.146 \mathrm{~m}^{3} / \mathrm{s}$ of discharge from main canal to division box and have $0.39 \mathrm{~m}$ of canal depth and $0.5 \mathrm{~m}$ bottom width. Secondary canal $2(\mathrm{SC} 2)$ off-take $0.087 \mathrm{~m}^{3} / \mathrm{s}$ pumped by motor pump to division box 2 that distribute to secondary canal 5(SC5) (Figure 2) which have capacity of $0.044 \mathrm{~m}^{3} / \mathrm{s}$ and canal depth of $0.26 \mathrm{~m}$ and bottom width of $0.28 \mathrm{~m}$. The secondary canal 3,4 and 5 also discharges $0.073,0.036$ and $0.044 \mathrm{~m}^{3} / \mathrm{s}$ of water and have canal bottom width of $0.36,0.26,0.28 \mathrm{~m}$ and canal depth of $0.29,0.25$ and $0.26 \mathrm{~m}$ respectively.

\section{Tertiary canal}

The tertiary canal (TC) also distributes $0.018 \mathrm{~m}^{3} / \mathrm{s}$ of discharge from secondary canal 4 and 5 (SC4 and SC5) to farm and have $0.23 \mathrm{~m}$ canal width and $0.16 \mathrm{~m}$ canal depth.

Table 4. Canals dimensions

\begin{tabular}{ccccccc}
\hline Canal type & $\begin{array}{c}\text { Water depth } \\
\text { in }(\mathrm{m})\end{array}$ & $\begin{array}{c}\text { Width } \\
\text { in }(\mathrm{m})\end{array}$ & $\begin{array}{c}\text { D/B ratio } \\
\text { MC }\end{array}$ & $\begin{array}{c}\text { Free board in } \\
(\mathrm{m})\end{array}$ & $\begin{array}{c}\text { Total canal } \\
\text { depth }(\mathrm{m})\end{array}$ & Discharge $\left(\mathrm{m}^{3} / \mathrm{s}\right)$ \\
SC1 & 0.40 & 0.74 & 0.54 & 0.20 & 0.60 & 0.524 \\
SC2 & - & 0.50 & 0.48 & 0.15 & 0.39 & 0.146 \\
SC3 & 0.19 & - & & - & - & 0.087 \\
SC4 & 0.15 & 0.36 & 0.53 & 0.10 & 0.29 & 0.073 \\
SC5 & 0.16 & 0.28 & 0.58 & 0.10 & 0.25 & 0.036 \\
TC1 & 0.11 & 0.23 & 0.48 & 0.10 & 0.26 & 0.044 \\
\hline
\end{tabular}

$\mathrm{MC}=$ Main canal, $\mathrm{SC}=$ Secondary canal and $\mathrm{TC}=$ Tertiary canal
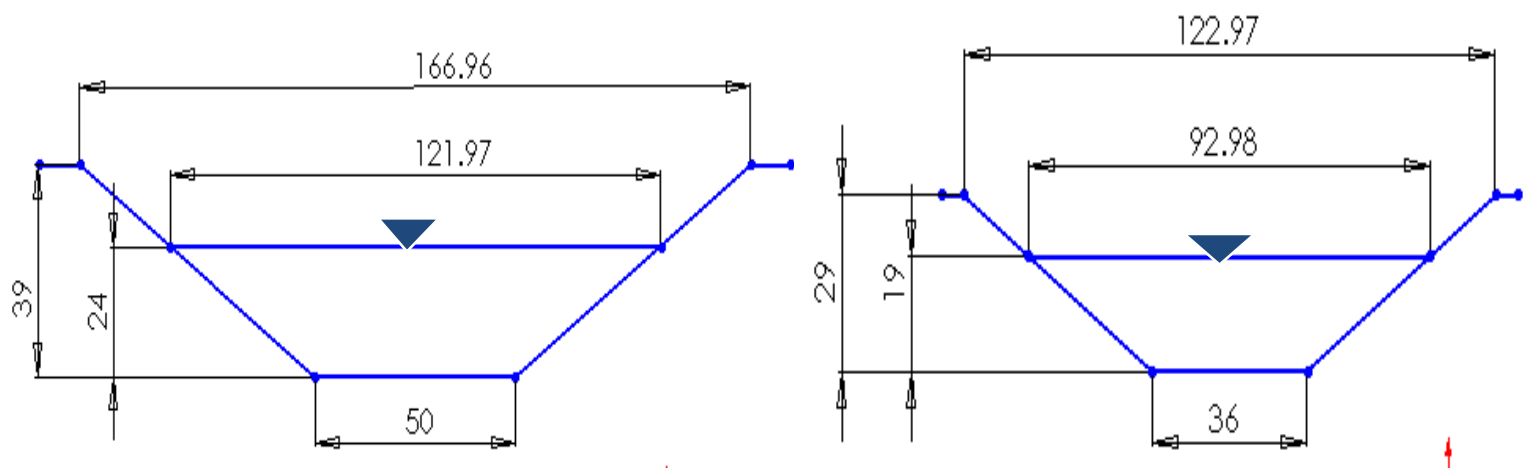

Figure 4. Secondary canal 1 and 3 (SC1 and 3) dimension in centimeter 

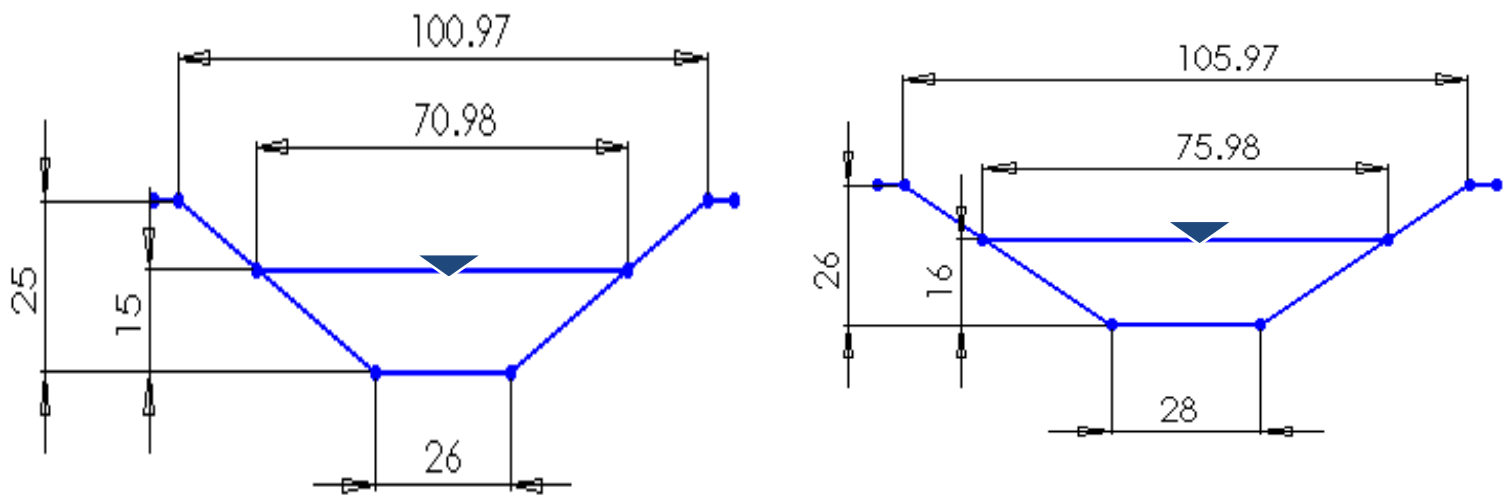

Figure 5. Secondary canal 4 and 5 (SC4 and SC5) dimension in centimeter

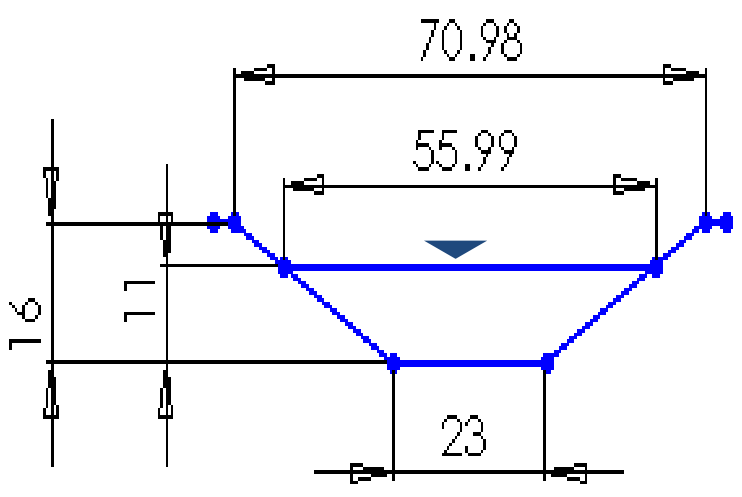

Figure 6. Tertiary canal (TC) dimension in centimeter

\section{Division box}

The discharge inlet to two way division box from secondary canal 1 (SC1) is $0.146 \mathrm{~m}^{3} / \mathrm{s}$ was divided into three.

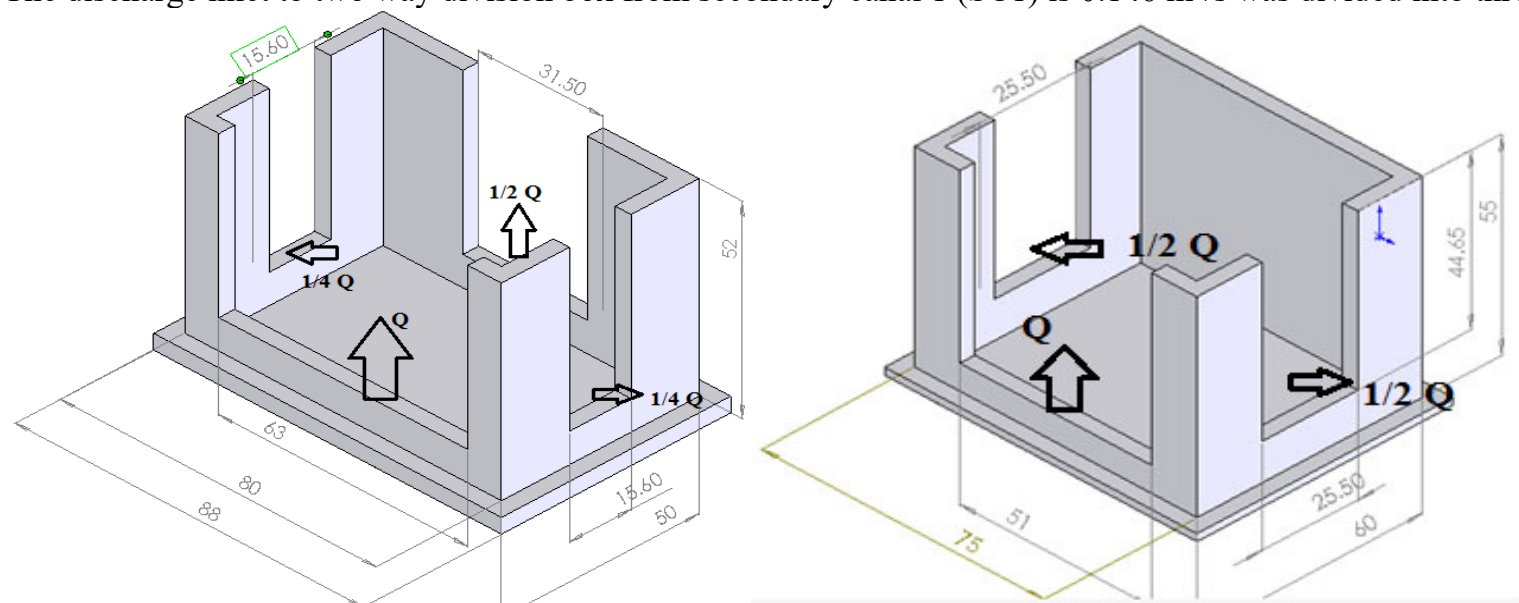

Figure 7. Three and two way division box 1 and 2

Figure 8. Two way division box 3

\section{CONCLUSION AND RECOMMENDATIONS}

Irrigation is highly expected to play a major role in the realization of Ethiopian food security and poverty alleviation strategy. From this important viewpoint, irrigation projects are widely studied, planed and implemented throughout the country. However, little or no attention is given to the monitoring and evaluation of the performance of already established irrigation schemes.

The scheme has trapezoidal shape of reservoir with a capacity of $2604 \mathrm{~m}^{3}$ live storage along with trapezoidal shape of main canal with average size of $161,59,38.2 \mathrm{~cm}$ at the top, bottom and depth respectively and maximum discharge capacity when gate was fully opened at off-take was $70 \mathrm{l} / \mathrm{sec}$.

The aim of this study was to redesign Mada Batu scheme to balance with current actual command area 
irrigated and water supply capacity of the scheme. The current redesigned capacity of main canal was 524 1/s with its corresponding dimensions $253.9,74$ and $60 \mathrm{~cm}$ at the top, bottom and depth respectively.

It is recommended for district irrigation development authority to solve the conflict between the farmers by making this research as base line information, further studies should also be carried out to determine required water supply to command area, to measure continuous water flow (spring water flow from reservoir) and detail land survey for detail scheme redesign.

Until the solution will come (redesign implemented) the district irrigation expert give training for farmers on water use and fix the schedule depending on crop water requirement. The canal maintenance and the reservoir cleaning are needed to increase the discharge and decrease the loss.

\section{ACKNOWLEDGEMENTS}

The authors thank Oromia Agricultural Research Institute (IQQO), for providing the scholarship and financial support for the research, Haramaya University, Malkesa Resarch Center and Zuwaiy Soil Laboratory Center for providing necessary field equipment and facilitating laboratory work and Gedab-Asasa Irrigation Development Authority for allowing me to get necessary documents and study site.

\section{REFERENCES}

Bayan Ahmed. 2017. Technical performance evaluation of mada batu small scale irrigation scheme , west arsi zone of oromia region. International journal of engineering research-online." 5(3):269-76.

CIA (Central Intelligence Agency). 2016. Ethiopia GDP and Economic Data https://www.cia.gov/library/publications/the-world-factbook/fields/2012.html\#84

FAO (Food and Agriculture Organization). 1989. Guidelines for Designing and Evaluating Surface Irrigation Systems. Irrigation and drainage paper No. 45. Rome, Italy.

IWMI (International Water Management Institute). 2010. Irrigation potential in Ethiopia:-Constraints and opportunities for enhancing the system.

Michael P. M. and John W. J. 1991. Calculating Area and Volume of Ponds and Tanks. SRAC. No. 89-385004516, USDA.

MoWR (Ministry of Water Resources). 2002. Water Sector Development Programme 2002-2016, Volume II: Main Report. Ministry of Water Resources, Federal Democratic Republic of Ethiopia, Addis Ababa.

NRMD (Natural Resources Management Directorate). 2011. The Federal Democratic Republic of Ethiopia Ministry of Agriculture Natural Resource Sector Small-Scale Irrigation Capacity Building Strategy for Ethiopia.

Rani,R.Y., Venkateswarao, B. and Sreekanth, S. 2011. Modernization of an Existing Irrigation Project by Performance Evaluation Using Performance Indicators. International eJournal of Mathematics and Engineering 141: 1273-92.

Robel Lambiso. 2005. Assessment of Design Practices and Performance of Small Scale Irrigation Structures in South Region. M.Sc. Thesis. Arba Minch University, Ethiopia

Seleshi Bekele Awulachew, D.J. Merrey, A.B. Kamara, B. Van Koppen, F. Penning de Vries and E. Boelee. 2005. Experiences and Opportunities for Promoting Small-Scale/Micro Irrigation and Rainwater Harvesting for Food Security in Ethiopia. IWMI Working Paper 98. Colombo, Sri Lanka.

Seleshi Bekele, Aster Denekew, Makonnen Loulseged, Loiskandl, W., Mekonnen Ayana, and Tena Alamirew. 2007. Water Resources and Irrigation Development in Ethiopia. Working Paper 123. Colombo, Sri Lanka. 